УДК $821.161 .2: 82.32$

DOI https://doi.org/10.26661/2414-9594-2020-2-28

\title{
ЖАНРОВИЙ СИНКРЕТИЗМ КАЗОК М. ЖУКА
}

\author{
Романова К. В. \\ аспірантка кафедри украӥнської літератури \\ філологічного факультету \\ Одеський національний університет імені I. I. Мечникова \\ вул. Дворянська, 2, Одеса, Україна \\ orcid.org/0000-0001-6908-6664 \\ romanovakv@ukr.net
}

Ключові слова: казка, жанр, казка-притча, казка-анекдот, казка- новела, комунікація, референція.
У статті розглядаються особливості жанрових форм у казках Михайла Жука. Вказано на жанрово-видові особливості казок та їх специфіку за характером комунікативної інтенції до цільової аудиторії. Виявлено синкретичні або змішані жанрові форми: казки-притчі, казки- байки, казки-анекдоти, казки-новели та з'ясовано, як відповідає референції до потенційного читача наповнення поетики казки семантичними кодами анекдоту, байки, притчі, новели. Серед функційно-тематичних різновидів казок М. Жука відзначено наявність пізнавальних, морально- дидактичних та пригодницько-розважальних творів. 3 огляду на дидактичну функцію казки, згідно 3 якою вона має ознайомити читача із загальновідомими нормами моралі, автор створює низку повчально- дидактичних творів, а саме: «Правда та неправда», «Неслухнянко», «Добро» та ін. Такі казки, як зазначено у статті, мають виразну виховну інтенцію- повідомлення, а також націлені на зображення та розкриття норм поведінки героїв чи іiі критику. Розглянуто особливість двоадресних казок М. Жука, яка полягає в поєднанні поетикальних ознак комунікативного посилу до дитини-читача 3 інтенціями висловлювання, спрямованими на дорослу аудиторію. Такі казки призначені дітям i, як правило, не переходять у категорію «казок для дорослих». Вказано на ремарочні комплекси, які виступають у ролі дидактичного елементу і служать засобом зближення та налагодження комунікативно-референтних відносин автора та реципієнта. Тому читачеві навіюється авторитетне (компетентне) ставлення автора до певної проблеми, наратор претендує на роль референтної групи і виступає зразком для наслідування в процесі формування поглядів та поведінки реципієнта. У казках-притчах («Спляча красуня», «Ма-зол-ке», «Про доброго короля Пустилихо») спосіб і характер дидактичної настанови створюють умови для комунікації із дитячою аудиторією молодшого віку. Кількашаровий тип висловлювання у казках двоадресного спрямування надає ознак художньої умовності, зокрема, алегоричності, яку здатні інтерпретувати читачі дорослого віку. 


\title{
GENRE SYNCRETISM OF M. ZHUK'S FAIRY TALES
}

\author{
Romanova K. V. \\ Postgraduate Student at the Department of Ukrainian Literature \\ of the Faculty of Philology \\ Odessa I. I. Mechnikov National University \\ Dvoryanska str., 2, Odessa, Ukraine \\ orcid.org/0000-0001-6908-6664 \\ romanovakv@ukr.net
}

Key words: fairy tale, genre, fairy tale-parable, fairy-taleanecdote, fairy-tale-short story, communication, reference.
The article considers the peculiarities of genre forms in the fairy tales of Mikhail Zhuk. The genre-species features of fairy tales and their specificity by the nature of the communicative message to the target audience are indicated. Syncretic or mixed genre forms are revealed: fairy tales-parables, fairy-tales-fables, fairy tales-anecdotes, fairy-tales-short stories and it is found out how the reference to the potential reader of filling the poetics of fairy tales with semantic codes of anecdotes, fables, parables, short stories corresponds. Among the functional and thematic varieties of $\mathrm{M}$. Zhuk's fairy tales, the presence of cognitive, moral-didactic and adventure-entertaining works is noted. Given the didactic function of the tale, according to which it should acquaint the reader with the well-known norms of morality, the author creates a number of instructive and didactic works, namely: "Truth and Falsehood", "Disobedient", "Good soul" and others. Such tales, as mentioned in the article, have a clear educational intention-message, as well as aimed at depicting and revealing the norms of behavior of the characters or its criticism. The peculiarity of M. Zhuk's twoaddress fairy tales is considered, which consists in the combination of poetic features of the communicative message to the child-reader with the intentions of expression aimed at the adult audience. Such fairy tales are intended for children and, as a rule, do not fall into the category of "fairy tales for adults". The remarking complexes are indicated, which act as a didactic element and serve as a means of rapprochement and establishment of communicativereference relations between the author and the recipient. Therefore, the author's authoritative attitude to a certain problem is suggested to the reader, the narrator claims the role of a reference group and acts as a role model in the process of forming the views and behavior of the recipient. In fairy tales-parables ("Sleeping Beauty", 'Ma-zol-ke", "About the good king "Pustylikho") the way and character of didactic instruction create conditions for communication with children's audience of younger age. The multi-layered type of utterance in bi-address fairy tales gives signs of artistic conventionality, in particular, allegory, which can be interpreted by adult readers.
Постановка проблеми. Творчість Михайла Жука-письменника багатогранна та унікальна, однак варто наголосити, що тривалий час до літературної спадщини автора не проявляли належної уваги. I лише в останні десятиліття літературні твори митця повертаються в поле зору дослідників, зокрема, Ярослав Поліщук, Агнешка Матусяк та Людмила Соколюк указують на високий рівень літературної майстерності автора, а Одеський літературний музей після дев'яносторічної перерви видає книгу М. Жука, у якій містяться не лише опубліковані раніше твори, а й уперше публікує низку раніше не відомих казок цього автора, що збереглися в архівах музею. Саме ці казки й стали об'єктом нашого дослідження.

Авторські казки Михайла Жука характеризуються наявністю жанрових різновидів, що диференціюються на основі проблематики, принципів побудови сюжету, сфери побутування, комунікативних стратегій висловлювання, ідейної спрямованості та референтності до адресата. За структурними ознаками сюжету його казки містять ознаки кумулятивної, авантюрної, легендарної, анекдотичної чи гумористичної та сатиричної оповідей. Відповідно до семантики вони можуть укладатись у три умовні групи: чарівні казки, казки про 
тварин, побутові казки, у межах яких знаходимо жанрово-видові різновиди. Аналізуючи проблематику авторської казки, будемо спиратися на спостереження Н. Тамарченко, Л. Брауде, Ю. Ярмиша, Л. Дерези, В. Кизилової, Г. Сабат щодо співвідношення літературної та фольклорної казок, сюжетно-образної структури, жанровостильових особливостей, а також на окремі дослідження авторських казок.

Мета статті. Мета пропонованої розвідки - проаналізувати міжжанрові особливості казок М. Жука та їх специфіку за характером комунікативної інтенції до цільової аудиторії; виявити синкретичні або змішані жанрові форми: казки-притчі, казки-байки, казки-анекдоти, казки-новели та з'ясувати, як відповідає референції до потенційного читача наповнення поетики казки семантичними кодами анекдоту, байки, притчі, новели.

Виклад основного матеріалу дослідження. Літературна казка є одним з найбільш динамічних жанрів, що зумовлено постійною референцією до традиції літературних версій казки і тих міжжанрових різновидів, які набули популярності у літературі нового часу. Така мінливість є однією 3 причин відсутності однозначного жанрового визначення казки у літературознавчих працях та чіткої їі класифікації.

Одним 3 найбільш уживаних $\epsilon$ визначення Л. Брауде: «Літературна казка - це авторський, художній прозаїчний або віршований твір, заснований або на фольклорних джерелах, або цілком оригінальний; твір переважно фантастичний, чародійний, що змальовує неймовірні пригоди вигаданих або традиційних казкових героїв і в окремих випадках орієнтований на дітей; твір, у якому неймовірне чудо відіграє роль сюжетотвірного фактора, служить вихідною основою характеристики персонажів» [1, с. 284]. Літературознавець та автор казок для дітей Ю. Ярмиш називає літературною казкою твір, у якому в чарівно-фантастичному або алегоричному розвитку подій $\mathrm{i}$, як правило, оригінальних образах та сюжетах у прозі, віршах та драматургії розв'язуються моральноетичні та естетичні проблеми [2, с. 28]. Базуючись на спостереженні дослідників, візьмемо також до уваги визначення В. Кизилової, що слугуватиме основою розуміння феномена літературної казки. Дослідниця називає літературною казкою «художній твір письменника, який, модифікуючи жанрово-стильові особливості фольклорної казки, формує новий за якістю авторський текст із різними інтертекстуальними елементами (цитатами, ремінісценціями, алюзіями тощо)» [3, с. 37].

Авторську назву «казка» поширюємо на короткі наративні твори, у яких спостерігається зрощення кількох жанрових i видових ознак, таких як: новелістична казка, казка-анекдот, казка-притча, казка-легенда, казка-сценка та ін. Серед функційно-тематичних різновидів казок M. Жука відзначаємо морально-дидактичні та пригодницько-розважальні твори. 3 огляду на дидактичну функцію казки, згідно 3 якою вона має ознайомити читача із загальновідомими нормами моралі, автор створює низку повчальнодидактичних творів, а саме «Правда та неправда», «Неслухнянко», «Добро» та ін. Такі казки мають виразну виховну інтенцію-повідомлення, а також націлені на зображення та розкриття норм поведінки героїв чи ii критику. Зміст пригодницько-розважальних казок побудований на захопливих подіях, що стають причиною незвичайних, а іноді й фантастичних пригод. Подібні ознаки властиві казці «Про Тхора-Тхорища», яка $є$ літературною обробкою народної казки із кумулятивним типом побудови сюжету.

Розглядаючи специфіку жанрових форм казок М. Жука у тематичному аспекті, спираємось на дослідженнях Володимира Проппа тематичних видів казок: казки про тварин, кумулятивні, побутові, новелістичні, небилиці, докучливі [4, с. 46-82] та (з огляду на комунікативні стратегіi) морально- дидактичні, пригодницько-розважальні й пізнавальні. Варто також взяти до уваги класифікацію на основі адресації до цільової аудиторії, адже однією з рис модерної авторської казки М. Жука є двоадресність, яку Н. Копистянська визначає як таку, що «має подвійного адресата: дітей і дорослих, оскільки може сприйматися на рівні фабульному та на рівні філософському» $[5$, с. 88$]$.

Наприклад, казки «Спляча красуня», «Слабий на очі», «Про доброго короля Пустилихо» та «Клопіт» мають яскраво виражений політичний підтекст $з$ ознаками сатири, що розширює комунікативну стратегію висловлювання, яке спрямоване не лише на аудиторію молодшого віку (слухача), а й дорослого читача (того, хто аудилізує - вголос читає текст для дитини). Аналізуючи специфіку (своєрідність) казки автора за ознакою комунікативно-референтної спрямованості, можемо виокремити такі категорії:

- казки для дітей молодшого віку («Дрімайлики малайцям»);

- казки для дітей старшого віку («Три глечики», «Про Тхора-Тхорища», «Кораблики», «Війна», «Водичка Молодничка», «Музики», «Циган і Чорт», «Старість», «Дядько та Дідько», «Добра душа», «Пшик», «Сливи», «Ох», «Неслухнянко» призначені як для самостійного прочитання дітьми старшого віку, так і для дорослих);

- двоадресні казки («Спляча красуня», «Ма-зол-ке», «Добро», «Клопіт», «Про доброго короля Пустилихо», «Ме»), що за особливостями 
поетики виявляють спрямованість на реципієнта як дитячого, так і дорослого віку.

Особливість двоадресних казок М. Жука полягає в поєднанні поетикальних ознак комунікативної інтенції до дитини-читача 3 інтенціями висловлювання, спрямованими на дорослу аудиторію. Такі казки призначені дітям і, як правило, не переходять у категорію «казок для дорослих». Автор майстерно поєднує цікаву для дитячого реципієнта розповідь із зрозумілою дорослому читачу іронією.

Пропонуємо розглянути таку особливість на прикладі казки-притчі «Спляча красуня». В основу сюжету покладено історію про дівчину, яка триста років спала, зачарована злим чарівником, події відбуваються «під лісом», а суб'єктами драматичної дії на рівні 3 людьми (дівчиною і мисливим) виступають птахи та звірі. Закохані у красу сплячої дівчини мешканці лісу намагаються визначитись стосовно неї. Спершу це роблять горобці: « - Вона буде нашою! - сказав найстарший горобець і надувся. - Вона давно наша, - ствердила горобчиха, крутнувши хвостиком» [6, с. 377]. Горобців прогнали ворони й почали вважати дівчину своєю, натомість їх зміг прогнати ведмідь, i ситуація із «привласненням» повторилась. Зрештою, красуню побачив мисливий, що прогнав ведмедя, побудував будинок і наважився пробудити дівчину від сну, однак наратор акцентує увагу на тому, що останній теж називає дівчину своєю без iї згоди: «-Вставай, красуне... Я добрий. Я тебе, як рідний, люблю! Я хатку побудував, я ведмедя прогнав. Ти тепер моя. Вставай!» [6, с. 379].

Повторювання подібних ланок-епізодів нагадує кумулятивну казку для дітей, такий прийом використовується автором 3 метою зацікавити слухача.

Сюжет казки «Спляча красуня» доповнюється розмовами тварин із відповідною для них артикуляцією, наприклад, мова горобців та ворон підсилюється вигуками: «Цвірінь, цірінь, чик-чаки...», «Кра! Вра! Бра! Мра!», що також має розважити та привернути увагу дитини-слухача. Однак, аналізуючи фабулу твору, специфіку нарації (представлення подій та вчинків героїв у їх причинно-наслідкових зв'язках), спостерігаємо розширення комунікативної спрямованості на реципієнта старшого віку, зазвичай, як вже зазначалося, ним стає той, хто читає вголос казку для дитини. Так, казка «Спляча красуня» має присвяту: «Присвячую Григорію Холодному» - українському вченому, сучаснику автора, жертві більшовицького терору, що конкретизує сприйняття дорослого читача. Окрім цього, елемент присвяти $є$ ознакою притчевості казки і вказує на жанрову модифікацію твору. Вже в його назві алегорично завуальовано образ Української Держави. Називаючи їі «Сплячою красу- нею», наратор використовує прийом алегоризації образної сфери, що свідчить про збагачення казки дидактичними ознаками притчі (варто зазначити, що, окрім назви, 3 відомою однойменною казкою твір має небагато спільного). Кумулятивний сюжет твору, що складається 3 чисельних «привласнень» героїні твору, переривається епізодом, у якому дівчина прокинулася, саме він служить кульмінацією твору: «Дівчина послухала усіх і сказала: - Коли я спала, то і горобці, i ворони, i ведмідь, і ти, мисливий, казали, як хотіли, а тепер я скажу, що я своя, а не ваша. Встала дівчина і пішла в люде» [6, с. 379]. Відповідно до ознак притчевого висловлювання у цьому епізоді проявляється імперативність повчань, авторитетність однозначно безапеляційних суджень. Абстрактна героїня постає як «... носій і джерело авторитетних переконань, що і створює наративну цілісність твору» [7, с. 35].

Наратор зазначає, що героїня проспала триста років, що теж містить алюзію до історичного минулого України. Завершуючи твір, наратор пролонгує установку на продовження кумулятивної казкової дійсності і поза текстом: «А мисливий накинувся на ведмедика, ведмедик на ворон, ворони на горобців - таке зчинилося! Почали ганятися одне за одним, а може, й досі ганяються, коли не притомилися або не порозумнішали. Остання фраза виявляється свого роду відгадкою та підтверджує гіпотезу читача про приховане порівняння: Красуня ж дівчина була Україна» [6, с. 379]. У цій казці наявне нетипове для цього жанру завершення, адже «спляча красуня» не залишається 3 мисливим, який їі врятував від ведмедя і пробудив від сну, а оголошує себе «своєю» і йде 3 лісу. Упродовж усього твору дівчина знаходиться напередодні важливих змін, а покидаючи топос лісу, змінює ключові установки існування в майбутньому. Такий елемент сюжету виконує дидактичну функцію і слугує певним моральним імперативом. Алегорична назва, присвята, характер оповіді та розв'язка твору свідчать про набуття казкою жанрово-стильових особливостей притчі і вказують на повчально- алегоричну модальність твору, пов'язану з призначенням двоадресному читачеві.

Проаналізуємо більш детально новелістичні казки-анекдоти М. Жука, звертаючи увагу на спосіб нарації, динаміку сюжетної будови та хронотоп.

Казка «Сливи» відзначається відсутністю чарівного елементу та героїв-тварин. Побутовий характер сюжету органічно проявляється на тлі анекдоту. Аналізуючи жанрові ознаки анекдоту у цих казках, ми маємо на увазі такі його ознаки, як:

- лаконічний та переважно діалогізований сюжет $з$ претензією на достовірність;

- випадково-ситуативна подієва основа твору; 
- наявність елементу сміхового катарсису та анекдотичного пуанту;

- дотепний, часто несподіваний чи парадоксальний фінал [7, с. 41].

Основні події твору окреслюються часопросторовими межами подорожі у сусіднє село. Герой казки, Макарь, вирушає в гості до свого товариша Мірошника. Характеризуючи героя твору, автор використовує притаманні йому як живописцю художньо-образні описові прийоми візуалізації.

Візуалізація образності проявляється завдяки палітрі кольорів та відтінків: «Одягнений так, як і слід у свято, - в чистеньке та новеньке. Навіть голова й лице, ніби жовточком помальовані: виблискують» $[6$, с. 415]. Художній опис зовнішності героя наближено до портретного. Наступний елемент характеристики героя закладений в імені. Наратор зазначає, що це саме той Макарь, про якого кажуть, «що він телят далеко ганяє», вказуючи на його належність до умовних персонажів розмовних жанрів (зокрема, анекдоту та прислів'я). Такий прийом, окрім відсилання до фольклорних першоджерел, може слугувати для знайомства та наближення (умовної ідентифікаціiі) героя й читача, адже в уяві читача постає заздалегідь сформований образ.

В експозиції цієї новелістичної казки-анекдоту $\epsilon$ пейзажна замальовка, що, окрім прямої функції ознайомлення реципієнта 3 часом та місцем дії, створює ліричний настрій. Цікаво, що в зав'язці з'являється незаявлений більше в тексті неозначений субстантивований суб'єкт уяви: «А по траві хтось ходе, ситий, мовчазний, задоволений», - він може сприйматися як своєрідний образ природної гармонії, екзистенційного феномена добробуту. За його допомогою наратору вдається передати відчуття повного задоволення від насиченого природними дарами серпневого дня. Внаслідок нагнітання літньої спеки, під час подорожі, наростає напруга у внутрішньому стані героя та проявляє себе голос порожнього шлунка як вияв докорів сумління. Адже подорож не дала очікуваного результату, товариша- Мірошника не виявилось вдома, а тому і омріяних гостинців, до яких «скупенький Макарь» готувався заздалегідь i «...ще вчора 3 вечора нічого не їв» [6, с. 415]. Характерні ознаки анекдотичної парадоксальної ситуації проявляються в епізоді, коли зголоднілому героєві на зворотному шляху доводиться задовольнити свій шлунок брудними сливами, які він сам напередодні викинув, обмастивши багнюкою, щоб не дістались «гулящій людині, волоцюзі якому-небудь, 3 тих анциболів, що по дорогах гуляються» [6, с. 416]. У творі подекуди розпізнаємо формальні ознаки драматургічної сценки, що написана у формі діалогу (реплік).
До розмови, окрім «внутрішнього голосу», долучається Баба та горобці, однак головним «співбесідником» залишається голос природних інстинктів, зокрема, голоду. У цьому епізоді вбачаємо кульмінаційний момент твору: природні людські потреби вступають у суперечку 3 інтенціями жадібного господаря. Такий елемент є типовим для анекдотичної ситуації, в основі якої - ефект парадоксу. У висловлюванні ж розпізнається дидактична інтенція: природні інстинкти перемагають розумові міркування господаря.

Домінантною у побутових казках М. Жука «Сливи» та «Ме» є тема господаря та його жадібності. Висловлювання у подібних казках виявляє риторичне спрямування, у них засуджується та висміюється певна риса характеру, і це завершує подальша дидактична настанова. Сюжет казки 3 ознаками анекдотичної ситуації та її сприйняття «Ме» містить антитезу. Жанрові коди анекдоту у творі прослідковуємо на рівні сюжету та способу нарації. В основі казки історія про сумлінного господаря та хитрого ледачого сусіда. На подібні сюжети натрапляємо як в українських фольклорних джерелах, так і в авторських казках. Зазвичай для сюжету про ледачого й працьовитого героя характерне використання прийому алегорії, що вказує на ознаки байки або наближеної до неї притчі. Однак персонажами казки «Ме»є реальні люди, це вказує на подібність до побутової казкианекдоту. Зав'язці передує експозиція, яка містить елементи пейзажної замальовки. Так, автор вважає за необхідне конкретизувати розташування сусідніх будинків, які належать героям твору: «Як стати лицем до схід сонця, то праворуч буде хата Грицька- Пасічника, а ліворуч ПанасаЦигана - через дорогу», - протилежність розташування яких підкреслює контрастність порівнюваних образів. Варто звернути увагу на ономастичні аспекти твору, адже наратор уникає опису персонажів, натомість додає до імен характерні прикладки, «пасічник» та «циган», які вказують на певні усталені риси поведінки. Роз'яснюється семантика імені другого персонажа: «Циганом же Панаса прозвали за його звичку вічно щось циганити. Колись він мав справжнє прізвище, та про це всі давно забули, як забув і сам Панас» [6, с. 418]. Власні назви в такому разі зумовлені авторською ідеєю та виконують стилістичну й образотворчу функції. Це зумовлене художнім задумом, жанром, а отже, інтенцією висловлювання та стилем поетики твору, що виявляє побутовий характер сюжету новелістичної казки-анекдоту.

I3 розвитком подій реципієнт дізнається про народження у Панаса-Цигана дитини й кумівські стосунки із сусідом Пасічником. У кульмінаційному епізоді твору властиве анекдоту представлення унікального курйозного випадку набуває характеру 
випадкового збігу обставин, що свідчить про «взаємодію індивідуальних ініціатив» [7, с. 41]. Розв'язка дії зумовлена не певним порядком, устроєм світу, а суб'єктивним баченням двох різних героїв. Спекулюючи бажанням дитини, Циган декілька разів отримує у подарунок мед, однак у зв'язку із надмірним нахабством останнього: «Як тільки у Панаса кінчався мед, то він ішов до кума і починав знову оповідати, що дитина кричить все Мe, та й Ме» [6, с. 419], Грицько-Пасічник наважується йому відмовити. При цьому він будує свої репліки за зразком фрази-прохання (у якій Циган не вимовляє останній звук у слові «мед»). Розраховуючи, що кум здогадається, Пасічник також не вимовляє деякі звуки у фразі-відмові. Кумедності ситуації додає прийом гри з читачем, він полягає у фонетичному шифруванні смислу та розпізнанні семантики фрази: «Ід-ку-до-чо-мам!» одночасно виконує функцію анекдотичного пуанту - неочікуваного перетворення ситуації внаслідок зміни точки зору [7, с. 42]. Ця ситуація також може служити і розв'язкою твору, адже спекулятивна фраза «Ме» отримала відповідну реакцію.

Спостерігаючи новелістичні елементи у сюжетній будові казок-анекдотів «Сливи» та «Ме», ми беремо до уваги такі характерні ознаки новели, як: стислість розповіді, обмеженість часопросторових меж, наявність композиційного осередку (переломного моменту), сюжетну однолінійність та зведення до мінімуму кількості персонажів [8, с. 127-134].

Варто звернути увагу на особливий спосіб мовлення в казках М. Жука. У висловлюванні виявляють себе декілька видів мовлення: мова наратора, репліки персонажів і невласне пряма мова передається ніби від імені автора, у мові якого проявляє себе голос дійової особи. У цьому проявляється двоплановість висловлювання: передається внутрішнє мовлення персонажа, його думки, настрої, озвучені автором. Такий прийом наближує мову твору до діалогів та ремарок автора у драматичному роді літератури.

Іншою характеристикою мови наратора вва- жаємо його всеохоплююче бачення ситуації: такий наратор виступає мудрим знавцем ситуації і передає свої знання реципієнту. Подібні ремарки часто $\epsilon$ короткими уточнюючими позасюжетними елементами і не відволікають реципієнта від фабульної складової частини твору. Вони, умовно кажучи, створюють обставини для формування у наратора та читача спільного способу бачення подій, покладених в основу художнього твору.

Ремарочні комплекси виступають у ролі дидактичного елементу і служать засобом зближення та налагодження комунікативно-референтних відносин автора та реципієнта. Отже, читачеві навіюється авторитетне (компетентне) ставлення автора до певної проблеми, наратор претендує на роль референтної групи й виступає зразком для наслідування в процесі формування поглядів та поведінки реципієнта.

Висновки. Модерна авторська казка М. Жука представлена не лише «чистими», традиційними, але й синкретичними або змішаними жанровими формами: казками-притчами (серед яких, зокрема, «Спляча красуня»), казками-анекдотами - «Ме», казками-новелами, такими як розглянутий у цій розвідці твір «Сливи». Також можна виявити не розглянуті у статті казки- байки, казки-оповідання, казки-сценки. У казках-притчах («Спляча красуня», «Ма-зол-ке», «Про доброго короля Пустилихо») спосіб і характер дидактичної настанови створюють умови для комунікації із дитячою аудиторією молодшого віку. Кількашаровий тип висловлювання у казках двоадресного спрямування надає образам ознак художньої умовності, зокрема, алегоричності, яку здатні інтерпретувати читачі дорослого віку. Наявність читацького досвіду (життєвого і літературного) дозволяє виявити також ситуативні комічні парадокси у неспівпадінні індивідуальних ракурсів бачення героїв у казках-анекдотах М. Жука («Ме», «Сливи», «Добра душа»).

\section{ЛІТЕРАТУРА}

1. Брауде Л.Ю. К истории понятия «литературная сказка». Известия АН СССР. Серия литературы $u$ языка. 1977. Т. 36. № 3.

2. Ярмиш Ю.Ф. У світі казки: літературно-критичний нарис. Київ : Радян. письменник, 1975. 145 с.

3. Кизилова В.В. Українська література для дітей та юнацтва: новітній дискурс : навчальний методичний посібник для студентів вищих навчальних закладів. Старобільськ : Вид-во ДЗ «Луганський національний університет ім. Тараса Шевченка», 2015. 236 с.

4. Пропп В. Фольклор и действительность. Жанровый состав русского фольклора. Москва : Наука. C. $46-82$.

5. Копистянська Н. Жанр, жанрова система у просторі літературознавства. Львів : Паїс. 2005. 88 с.

6. Жук М.І. Казки. Дім князя Гагаріна : збірник наукових статей і публікацій. Одеський літературний музей. Вип. 6. Частина 1. Одеса : Сімекс-прінт, 2011. 424 с.

7. Теория литературных жанров : учебное пособие для студентов / под ред. Н.Д. Тамарченко. Москва : Издательский центр «Академия», 2011. 256 с.

8. Денисюк І. Поетика новели. Жовтень. Львів. 1969. № 10. С. 127-134. 
9. Давидюк В.Ф. Доісторичне поле української казки. Концепції і рецепції. Луцьк : ПВД «Твердиня», 2007. С. 4-45.

10. Дереза Л.В. Російська літературна казка п. пол. ХІХ ст. у системі жанрів романтизму : автореф. дис. ... д-ра філол. наук. Таврійський національний університет ім. В.І. Вернадського. Сімферополь, 2005. 39 c.

11. Сабат Г.П. Казки Івана Франка як естетико-поетикальна система : автореф. дис. ... д-ра філол. наук : спец. 10.01.06; 10.01.01. КНУ ім. Т. Шевченка. Київ, 2009. 32 с.

\section{REFERENCES}

1. Braude, L.Ju. (1997). K istorii ponjatija "literaturnaja skazka" [On the history of the concept of "literary tale"] [in Russian].

2. Davydjuk, V.F. (2007). Doistorychne pole ukrai'ns'koi'kazky [Prehistoric field of Ukrainian fairy tales]. Luc'k: "Tverdynja" [in Ukrainian].

3. Denysiuk, I. (1969). Poetyka Novely [Poetics of short stories]. Zhovten. Lviv [in Ukrainian].

4. Dereza, L.V. (2005) Rosijs'ka literaturna kazka p. pol. XIX st. v systemi zhanriv romantyzmu: avtoref. dys. ... d-ra filol. nauk: spec. [Russian literary tale of the first half of the XIX century in the system of genres of romanticism: abstract of the dissertation of the doctor of philological sciences] (Phd Thesis) Simferopol': Tavrijs'kyj nacional'nyj universytet im. V.I. Vernads'kogo [in Ukrainian].

5. Zhuk, M. (2011). Fairy tales, Dim kniazia Haharina : zbirnyk naukovykh statei i publikatsii [House of Prince Gagarin: Collection of scientific articles and publications]. Vol. 6, No. 1. Odesa [in Ukrainian].

6. Kopystianska, N. (2005). Zhanr. Zhanrova Systema U Prostori Literaturoznavstva [Genre. Genre System and Spaces of Literary Knowledge]. Lviv : Pais [in Ukrainian].

7. Kyzylova, V.V. (2015). Ukrai'ns'ka literatura dlja ditej ta junactva: novitnij dyskurs: navch.-metod. posibnyk dlja stud. vyshhyh navch. zakl. [Ukrainian literature for children and youth: the latest discourse]. Starobil's'k: Vyd-vo DZ "Lugans'kyj nacional'nyj universytet im. T. Shevchenka" [in Ukrainian].

8. Propp, V. (1976). Folklor Y Deistvytelnost / Zhanrovyi Sostav Russkoho Folklora [Folklore and reality / Genre composition of Russian folklore] Moskva : Nauka [in Russian].

9. Sabat, G. (2009). Kazky Ivana Franka jak estetyko-poetykal'na systema [Tales of Ivan Franko as an aesthetic and poetic system] (Phd Thesis). Kyiv: Universytet im. T. Shkvchenka [in Ukrainian].

10. Tamarchenko, N.D. (2011). Teoryia lyteraturnykh zhanrov [Theory of literary genres] [in Russian].

11. Jarmysh, Ju.F. (1975). U sviti kazky: literaturno-krytychnyj narys [In the world of fairy tales: literarycritical essay] Kyiv : Radjan. Pys'mennyk [in Ukrainian]. 